\title{
Nelly Don's 1916 pink gingham apron frock: an illustration of the middle-class American housewife's shifting role from producer to consumer
}

\author{
Mikyoung Whang ${ }^{1 *}$ and Sherry Haar ${ }^{2}$
}

\footnotetext{
* Correspondence:

whangm@centenarycollege.edu

${ }^{1}$ Communication and Fine Arts, Centenary College, 400 Jefferson St., Hackettstown, NJ 07840, USA Full list of author information is available at the end of the article
}

\begin{abstract}
Nelly Don created a stylish, practical, affordable pink gingham housedress in 1916, quickly selling out her first order of 216 dresses at Peck's Dry Goods Company in Kansas City. This study investigated the reasons behind the success of her dress, and found that during the early 20th century, women's roles shifted from that of producer to consumer, and that clothing was a visible reflection of this shift. Specific design attributes and social appeal contributed to the success of the housedress. Integrating trendy design elements into an affordable housedress along with the growing demand for a stylish, yet practical housedress induced by consumption culture in the early 20th century facilitated the success of Nelly Don's pink gingham housedress. As such, Nelly Don's 1916 housedress reflected social and cultural change in this transitional period, and exemplified the shifting role of the middle-class American housewife by offering an alternative to the traditional Mother Hubbard housedress as well as a lifestyle free of long hours spent sewing.
\end{abstract}

Keywords: Nelly Don; Housedress; Consumerism; Housewife; Women's roles

\section{Introduction}

Nell Donnelly Reed (maiden name, Ellen Quinlan) (1889-1991) (Figure 1), often called "The grand lady of the garment industry," established the Donnelly Garment Company (DGC) in 1919 in Kansas City, Missouri, with her first husband, Paul Donnelly (Snider 1991). By 1929, the DGC employed 1,000 people and made 5,000 dresses a day, and in 1947 was one of the largest dress manufacturing companies in the U.S. (O'Malley 2006). The DGC was known for producing affordable, quality garments, catering to middle-class women until it was sold in 1956 (McMillen \& Roberson 2002; O’Malley 2006). Nell Donnelly Reed, a middle-class housewife who left her rural home for Kansas City at age 16, worked as a stenographer, married and went to college at Lindenwood College in St. Charles, Missouri in 1906 (McMillen \& Roberson 2002; O'Malley 2006) utilized her sewing and designing talents to become one of the most successful woman entrepreneurs in the early 20th century.

Born on a farm in Parsons, Kansas, Nell learned to sew from her mother and her oldest sister, and she excelled at it, often creating her own patterns. When Nell became 


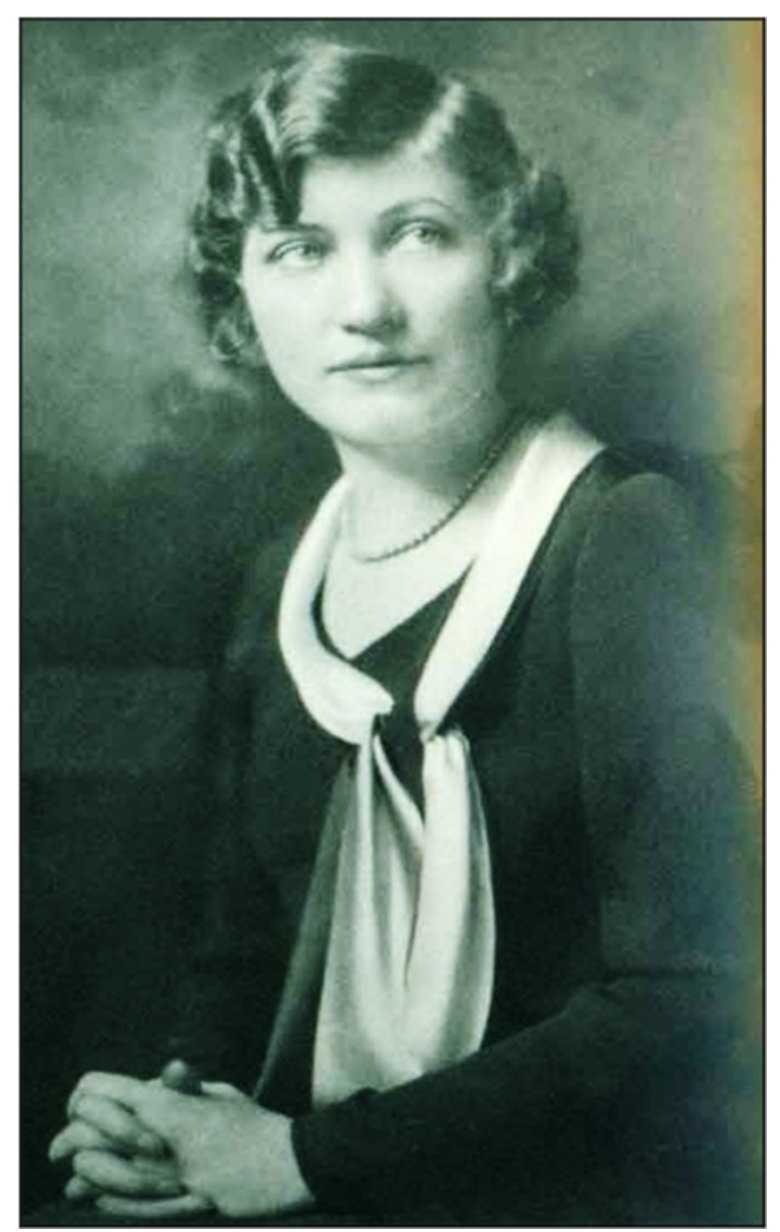

Figure 1 Photograph of Nelly Don, 1926. From "Nelly Don: A Stitch in time," by T. M. O'Malley 2006, MO: The Covington Group, p. 23.

a housewife, she created tasteful housedresses for herself and for her family, believing that housedresses should be as pretty and attractive as street clothes. Since her friends could not find such charming dresses they often asked Nell to make dresses that they could purchase, and encouraged her to sell her dresses to local retailers (McMillen \& Roberson 2002; O'Malley 2006). In 1916, Nell took her pink gingham housedress (Figure 2) to Peck's Dry Goods Company, a leading Kansas City dry goods store, located at 1044 Main Street. She received an order for 18 dozen dresses which upon fulfilling immediately sold at \$1 apiece (McMillen \& Roberson 2002; O’Malley 2006). This success led to the establishment of the DGC. Nell adopted the persona of 'Nelly Don,' which was both a label of the company and her moniker; therefore, in this paper, Nelly Don refers to Nell Donnelly Reed herself as well as to Nelly Don dresses.

Scholars who have studied Nelly Don's work maintained that the only housedress available when Nell created hers in 1916 was the Mother Hubbard, a shapeless, dull colored-dress available at the dry goods store for 69 cents (McMillen \& Roberson 2002; O’Malley 2006; Snider 1991; Wilding 1987). However, sewing patterns of housedresses and a variety of ready-made housedresses were promoted in advertisements, fashion columns, and mail-order catalogs around 1916, indicating that housewives did indeed 


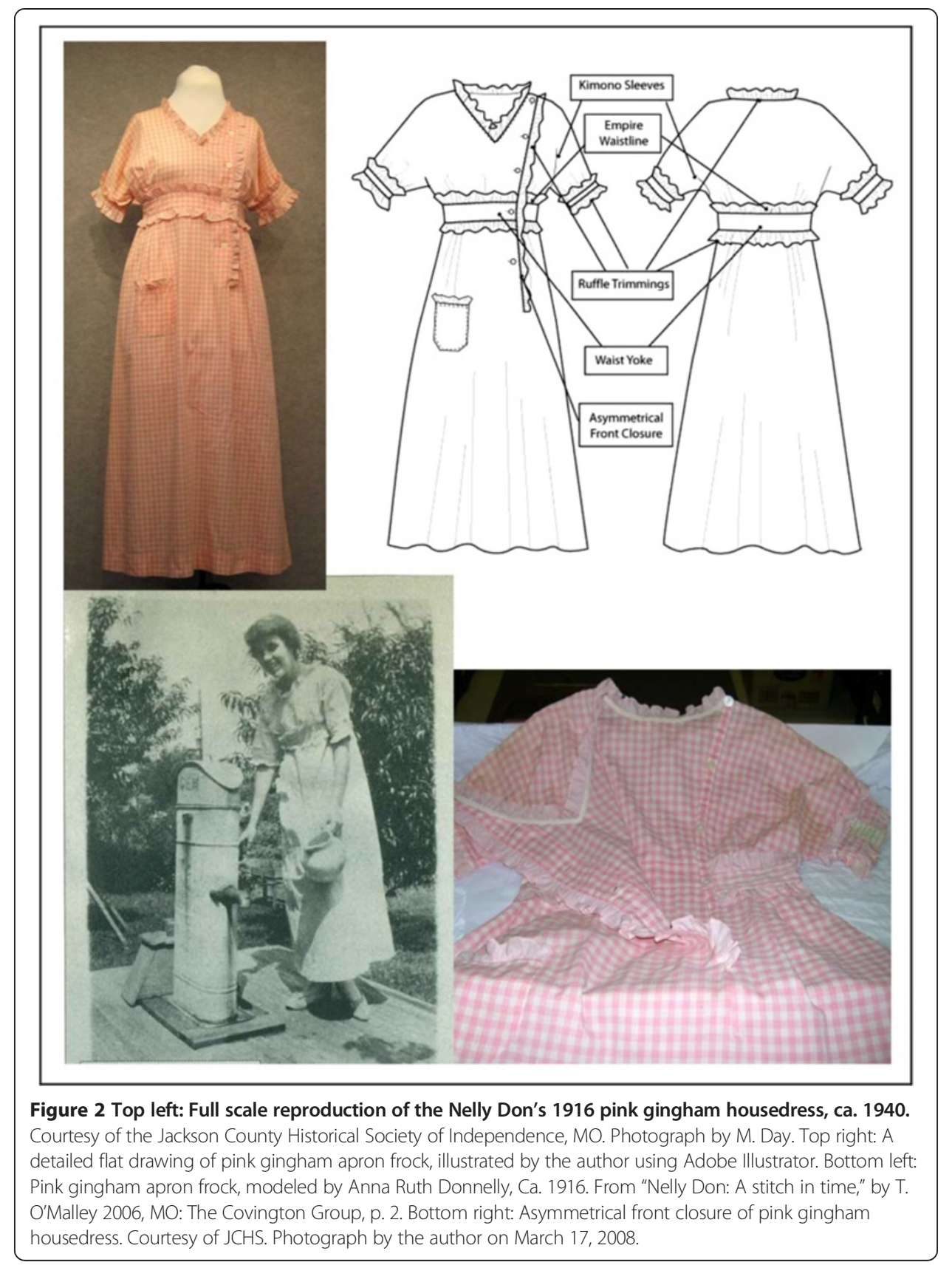

have housedress options. Nonetheless, all 18 dozen Nelly Don pink gingham housedresses sold out in one day, which invites an analysis as to why it was so popular. The purpose of our research was to explore the reasons behind the success of Nelly Don's pink gingham 1916 housedress, and examine the role of the housedress in the lives of middle-class American women at the time.

Our thesis offers two main reasons why Nelly Don's 1916 housedress was wellaccepted; first, its design incorporated popular design elements including kimono sleeves, empire waistline, waist yoke, asymmetrical front closure, and ruffle trimmings sensibly, which warranted a successful sale. Secondly, mass advertising and media articles instilled in women a desire to look pretty while doing housework. Our research 
revealed that industrialization influenced the cultural, social, and political environment and in turn women's fashion as well as their roles and lifestyle. Specifically, industrialization modernized American households and society, generating a consumption culture in the early 20th century. In this context, Nelly Don's 1916 housedress reflected current cultural, social, and fashion trends in this transformative period and serves as a material culture example of dress reflecting middle-class American women's shifting roles.

\section{Methods}

To support our thesis, we examined extant housedresses made in the 1900s and 1910s located in various museums (Kansas City Museum, Missouri Historic Costume and Textile Collection, Jackson County Historical Society, MO, and Kansas State University Historic Costume and Textile Museum). Housedress articles, advertisements, and sewing patterns from about 1911 to 1916 were surveyed from ladies' popular magazines (Ladies' Home Journal, The Delineator, Good Housekeeping, and Harper's Bazaar), mail-order catalogs (Sears, Roebuck and Co. and Montgomery Ward Co.), and catalogs of department stores (B. Altman \& Co. and Gimbel Brothers), small clothing manufacturers (Perry, Dame E Co. and National Cloak and Suit Co.), and clothing pattern companies (The Home Pattern Company and The Standard Fashion Company). This was the period when Nelly Don stayed home after graduation from college and produced dresses prior to her marketing debut. Other sources included interviews with L. Sheerer who is a former employee of the DGC, Mr. O’Malley who is Nelly Don's great nephew, and Mr. Jackson who is a director of the Jackson County Historic Society. Also examined were DGC documents, biographical books on Nelly Don, and publications about early 20th century society, culture, women, and fashion.

\section{Women's fashion influenced by cultural and social changes in the early 20th century}

Women's roles and lifestyle altered due to radical changes in the cultural, social, and political surroundings in the early 20th century. Women, whether they were working class, middle-class, or well-off, felt the rapid change. Progressivism, one of the outcomes of rapid industrialization, began in this era. Reformers who believed in equal rights, humanity, and democracy strived to eradicate the problems (caused by rapid industrialization) that occurred in urban areas, and furthermore fought for the overall improvement in the quality of life (Progressive Era in America n.d.). Under these circumstances, women were avidly following the "New Woman" who was portrayed as the symbol of freedom, individuality, and modernity. Women began to appear in the public sphere more often than in previous years and were willing to use their spare time to participate in various outdoor activities and women's clubs either for self-enhancement or for social and political causes (Hill 2004).

Club women and settlement workers believed that they could upgrade the quality of life by cleaning house in local, state, and federal entities or agencies; women workers turned to unions and the National Women's Trade Union League to fight for better wages and working conditions. Housewives also found their households changing; they were less and less expected to be producers in the home and more and more consumers in the marketplace (Schneider \& Schneider 1993). Thus, while the lives of middle-class women in the 19th century tended to revolve around home life, women 
in the early 20th century ventured into jobs, politics, and culture outside the domestic sphere (Kidwell \& Christman 1974; Tortora \& Eubank 2010). Ogden (1986) indicated housewives' greater awareness of the outside world of this era by stating, "Women in the early decades of the new century wanted the vote, jobs, peace, birth control, and education. But they also wanted families and stable homes. They wanted to wear sports clothes and business attire, but they also wanted alluring evening gowns and fashionable 'at-home' wear. Women began to pay millions of dollars for makeup from Elizabeth Arden and Helena Rubenstein, new companies that took advantage of the advertising machinery originating in the ladies' magazines of the late 1800s" (p. 139).

Participation in various outdoor and sports activities, as well as motoring brought about specialty clothing that was comfortable and practical (Ewing 2001; Totora \& Eubank 2010). The baroque opulence of shape and decoration of the Edwardian styles were replaced with simpler and straighter garments with much less decoration, reflecting the spirit of the time (Ewing 2001; Hill 2004). World War I (1914-1918) accelerated this trend as female war workers sought simple, comfortable styles that also showed a military influence including big patch pockets, caplets, epaulets and metallic buttons (Hill 2004).

The popularity of linear Far Eastern-inspired clothing styles in the early 20th century (Kim \& Delong 1992; Ewing 2001; Mears 2005) hastened this trend as well. Long's (1914) article in Ladies' Home Journal illustrated the Far Eastern influence on women's fashion well: "...Really this season we are borrowing from almost every Oriental country and the effect is most picturesque: we adapted the Persian lampshade tunic and headdress, the Chinese colors and embroideries, kimono effects and collars from Japan and burnoose draperies from Arabia" (p. 24).

\section{The Housedress}

The housedress in this study refers to the inexpensive, washable work dress worn by middle-class women with limited or no domestic help, not the elaborate version of at-home attire worn by the wealthy with domestic servants (S. Helvenston Gray, personal communication, January 6, 2011). This definition excludes other occasion dresses for shopping, walking, sports activity, and formal events. A morning dress, work dress, wash dress, house frock, apron frock, house gown, tub frock, dressing sack, wrapper, or bungalow apron also refers to the housedress (or house dress). In the 19th century, the Mother Hubbard was the middle-class housewives' housedress characterized by its loose fit (typically fitted only at the shoulder yoke) and plain fabric (Calasibetta \& Tortora 2003, Wilson \& Newby 2004). See Figure 3. In addition, the Mother Hubbard served as a maternity dress and was suitable for aged women and growing children (Helvenston Gray n.d.). Despite its multi-functional role, the Mother Hubbard was viewed as old-fashioned in the early 20th century (Austin 1906; Maternity frocks 1915). Austin (1906) asked rhetorically in her article in Good Housekeeping, "How many women abhor the loose ugliness of the wrapper and the dressing sack for wear about the house and long for a little frock that will combine comfort with neatness-that will allow freedom for the thousand and one morning home duties and yet preserve a trimness suitable for the garden or the veranda" (p. 186).

The style of housedresses progressed from loose fitting and plain in the early $1910 \mathrm{~s}$ to those with increased fit at the waist and inclusion of fashionable elements in the 


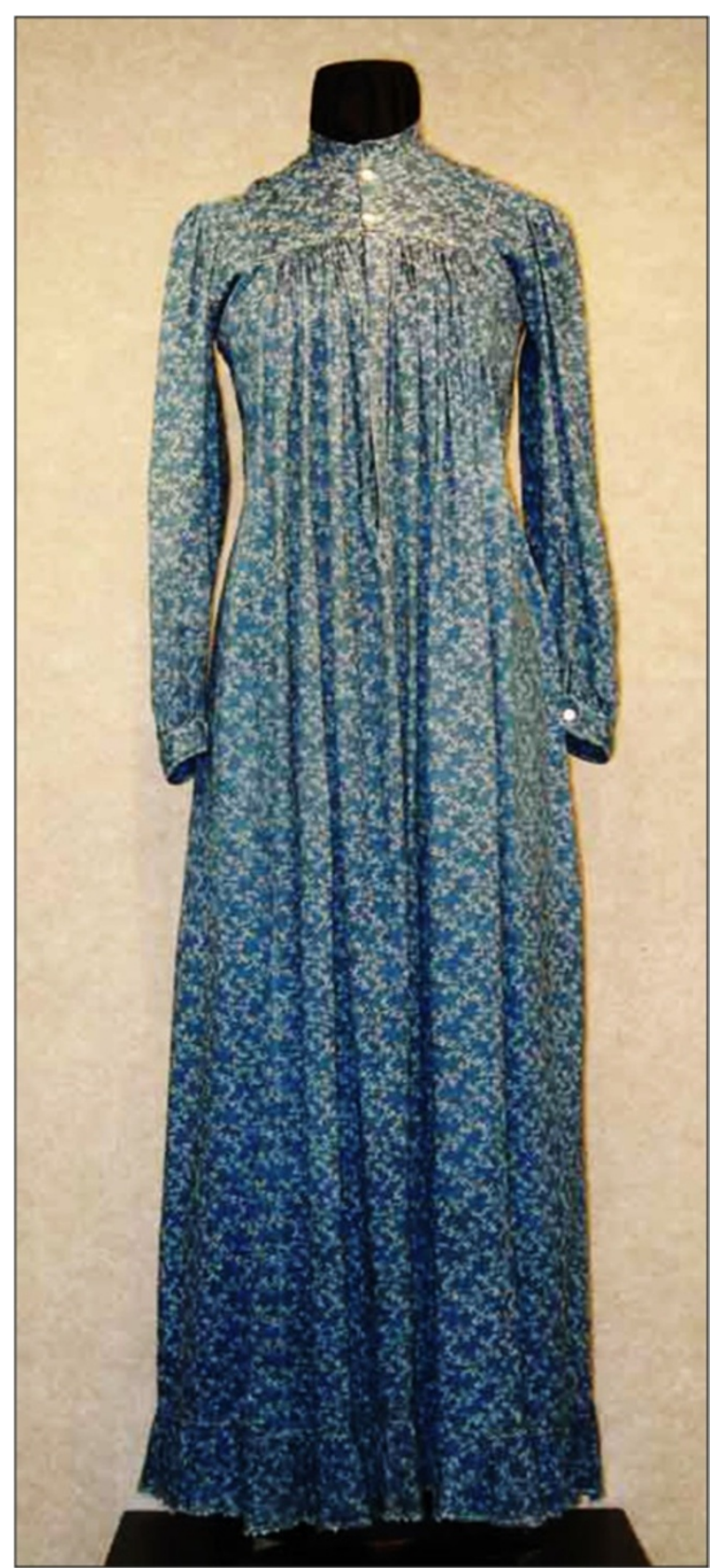

Figure 3 Mother Hubbard, blue calico print dress, Ca. late 1900s Courtesy of HCTM at Kansas State University, gift of Mrs. Ruth Sanderson. 83.15.12. Photograph by M. Day.

mid-1910s. Gathers or pleats controlled the fitted waistline or waist yoke, the hemline was shortened, and use of decorative trims, buttons, and contrasting fabrics on the collars, cuffs, and faced openings were prevalent. A writer in the Ladies' Home Journal depicted this progress, maintaining that "a work dress for the housewife must first be comfortable, second, easy to get into, and there is no reason why it should not be pretty and becoming as well" (One-piece work dress 1910, p. 34). Housedress ads in the 1914 Sears, Roebuck and Co., Gimbel Brothers 1915, and 1916 Montgomery Ward Co. catalogues illustrated the evolved housedress designs (Figure 4). A Montgomery 


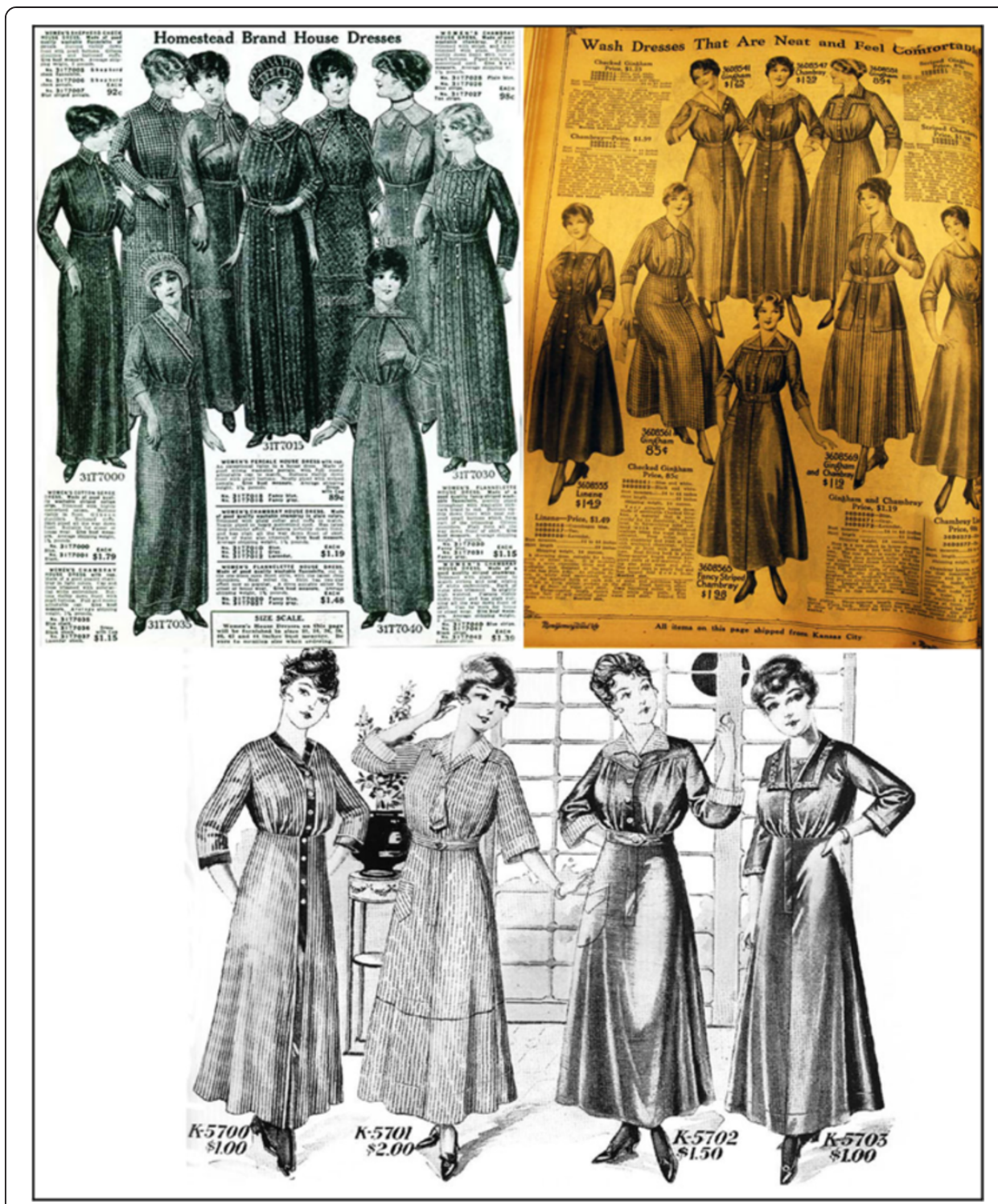

Figure 4 Housedress models with fitted waist and decorative elements. Left: Homestead Brand housedresses in Sears, Roebuck and Co. catalog, 1914. From "Everyday Fashions 1909-1920: As Pictured in Sears Catalogs," by J. Olian (Ed.), 1995, New York: Dover Publications, p. 36. Right: Montgomery Ward Co., 1916 Spring/Summer catalog, p. 110. Bottom: Gimbel's illustrated 1915 fashion catalog, by Dover Publication's republication of 1915 Gimbel Brothers catalog, 1994, New York: Dover Publication, p. 57.

Wards' model was described as a "lovely house dress which is really sufficiently elaborate for a porch or street wear" (Wash dresses that are neat and feel comfortable 1916, p. 110). Updated style features of the models included the fitted and slightly raised waistline, waist yoke, center front button closure, and decorative trims.

\section{Nelly Don's 1916 pink gingham housedress}

According to David Jackson, Director of Archives and Education at Jackson County Historical Society (JCHS), Independence, Missouri and the record at the museum, the Nelly Don housedress examined in this study is a replica of the original 1916 pattern 
with which Nelly Don made her initial marketing debut to Peck's Dry Goods Company in downtown Kansas City, Missouri. The dress was retrieved from the home of Mrs. Swope by neighbor Jane Flynn who donated it to the JCHS in 2002. Mrs. Swope, a former employee of the DGC, apparently bought the pink gingham housedress at a sales event offered only to the employees while she was working for the company around 1940. A paper tag stapled to the lower left inner sleeve of the dress contained the following hand-written notes: 1916, Nelly Don, $\$ 2.98$.

The body of the housedress is made of medium-weight pink-and-white gingham where the weave results in checked repeat. The fiber content of the replica is thought to be cotton or cotton blend since we were not allowed to remove a fiber for testing. However, the fiber content of the original 1916 pink gingham dress is likely to be $100 \%$ cotton based on the price of the gingham (six and a half cents a yard) (Spilsbury 1952) and also the fact that synthetic fiber such as polyester was not invented around that time. Rayon fiber was invented earlier than 1916 but not widely used prior to the 1920s in the U.S. (Tortora \& Eubank 2010). Watson (1907) defined gingham as yarn-dyed smooth, close cotton usually woven in checks or stripes. Due to cotton gingham's practicality, it was used for housedresses, aprons, blouses, shirts, and children's clothes. Ladies' magazines described its use well throughout the late 19th and early 20th centuries, "The new ginghams, beautiful in color, design, and texture, make charming house gowns, which are unlined and constructed in simple fashion so that they may be easily laundered" (Dainty summer gowns 1898, p. 295). Stan (1908) commented on the suitability of gingham fabric for a morning dress (housedress) by stating, "A light weight, striped percale, with white background, is pretty. However, these soil easily, and darker goods such as ginghams will look well for a much longer time without laundering" (p. 72).

As shown in Figure 2, Nelly Don's housedress is an above ankle-length one-piece dress made of gingham fabric. Shaping was created through the waist yoke by controlling pleats in the bodice and skirt sections. The dress has an empire waistline, kimono sleeves, and an asymmetrical front closure with five mother-of-pearl buttons and buttonholes. The asymmetrical front closure starts at the left shoulder and ends at the hip area allowing for ease of dressing. The ruffled trim, constructed from a woven fabric in a coordinating solid pale pink color, trims the neckline, sleeve bands, waist yoke, front closure, and the opening of the patch pocket. There was extra ease, around one inch, at waist seams for alterations. The hem allowance is two inches, and most of the seam allowances are bias-bound with a bias tape, in a pale pink color.

\section{Reasons for the success of Nelly Don's 1916 pink gingham housedress}

During the early 1900s, industrialization and urbanization altered women's lives permanently in both private and public spheres through technological advancement and mechanization, and in turn social progress. As noted by Ewing (2001), the connection between social and fashion change was most noticeable in this period; as society modernized, so did fashion. The housedress was a visible reflection of this shift, progressing from the Mother Hubbard style to that with fashionable and decorative features, one of which was Nelly Don's 1916 housedress. In the following sections we explored why Nelly Don's housedress was widely accepted, focusing on two particular reasons: stylish design features and the influence of the consumption culture on society. We believe 
the sensible incorporation of current fashion design elements contributed to Nelly Don's housedress success. Analysis of garment designs presented in magazines, catalogues, and extant garments support this point. Next, we explored the social appeal of its success, bolstered by housedress ads in ladies' magazines that urged women to look pretty even at home by wearing the latest style, which surely instilled a desire for staying current and modern (Hill 2004). Thus, it is likely that these ads predisposed and prepared consumers to accept Nelly Don's housedress. To support this claim, we delved into the preliminary information on the modernization of society and household, and consumption culture.

\section{Design appeal: incorporation of popular design elements}

Numerous garments, of both high and low price-point, from 1911 to 1916 were designed with the kimono sleeve, empire waistline and/or waist yoke, which manifested their popularity. Many garments in this period also used ruffle trimmings and an asymmetrical front closure. "Being popular" in this research denotes when certain design elements or styles were incorporated into garment designs frequently. The survey of garment designs presented in the magazines, catalogues, and extant garments from the period studied provided evidence of the popular design elements, speaking to the success of Nelly Don's housedress. We believe the pink gingham housedress was well-designed with popular design elements including kimono sleeves, empire waist, waist yoke, ruffle trimmings and asymmetrical front closure.

A dressmaking pattern in the popular Asian style with kimono sleeve on a "tunic dress" (dress with overskirt) with raised waistline was presented by Mrs. Ralston in her November 1913 article, “About the new ideas in clothes one sees in Paris" in Ladies' Home Journal (Figure 5). The fashion editors of Ladies' Home Journal discussed "new in cut and fit" of coats and coat suits by mentioning that "the intricate finish of the strictly tailored garment is entirely eliminated; padding, canvas, interlining and machine stitching have vanished, in their place we have loose-fitting kimono or Raglan models" (Coats and coat suits for spring 1914, p. 95).

Further examples of less tailored dressmaking patterns for coats and dresses with kimono sleeves, raised waistlines and/or waist yoke designs are illustrated in The Delineator, March 1914 (Figure 5). These design elements also appear in ready-to-wear and couture garments, as seen in the 1915 ready-to-wear tea gowns from Harper's Bazaar (Figure 5) which sold for \$18.50 each. Lady Duff-Gordon (Lucile, 1863-1935), a prominent couturier, introduced her designs in 1915 Harper's Bazaar, showing kimono sleeves, empire waist, and/or waist yoke (Figure 5). It was apparent that kimono sleeves, empire waist and/or yoke designs were popular and dressmaking pattern designers as well as ready-to-wear and couture designers utilized them in a variety of garments from about 1911 to 1916, which argues for the design elements cutting across garment type and socioeconomic status.

Many examples were found of incorporating ruffle trimmings into a range of garments such as blouses, summer frocks (dresses), and special occasion dresses from 1911 through 1916 (Whang 2011). The subsequent article written by Merritt (1912) entitled, "What I see in New York" from Ladies' Home Journal, described the "new" ruffles for the reader who wanted "a touch of newness or prettiness or of the unexpected" for the upcoming spring season with: "all the newest models I have seen in New York have the dainty frill at the wrists and side front" (p. 33). The "lingerie waist" was one of the garments on this 


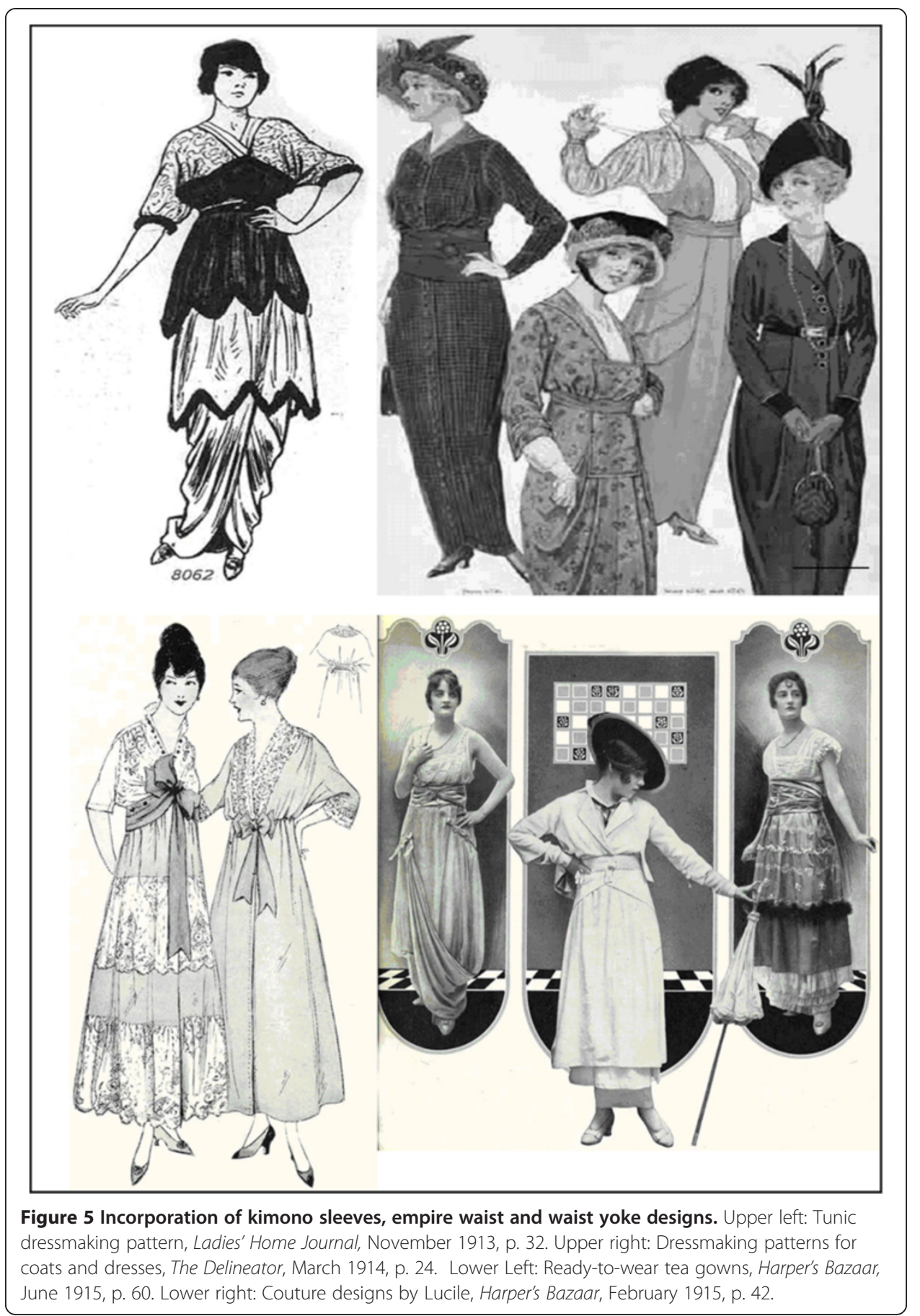

page trimmed with ruffles at the wrists and side front (Figure 6). A Bonwit Teller \& Co 1915, ready-to-wear dress was described as the "epitome of daintiness" with its rows of ruffles (Figure 6). Another example was the home-made cotton gingham check dress (Figure 6) examined at the Kansas City Museum, Kansas City, Missouri that was trimmed with organdy ruffles at the collar and cuffs. As ruffle trimmings were one of the most popular design elements in women's fashion of the era, it is not surprising that Nelly Don included such a feminine touch for her housedress. 


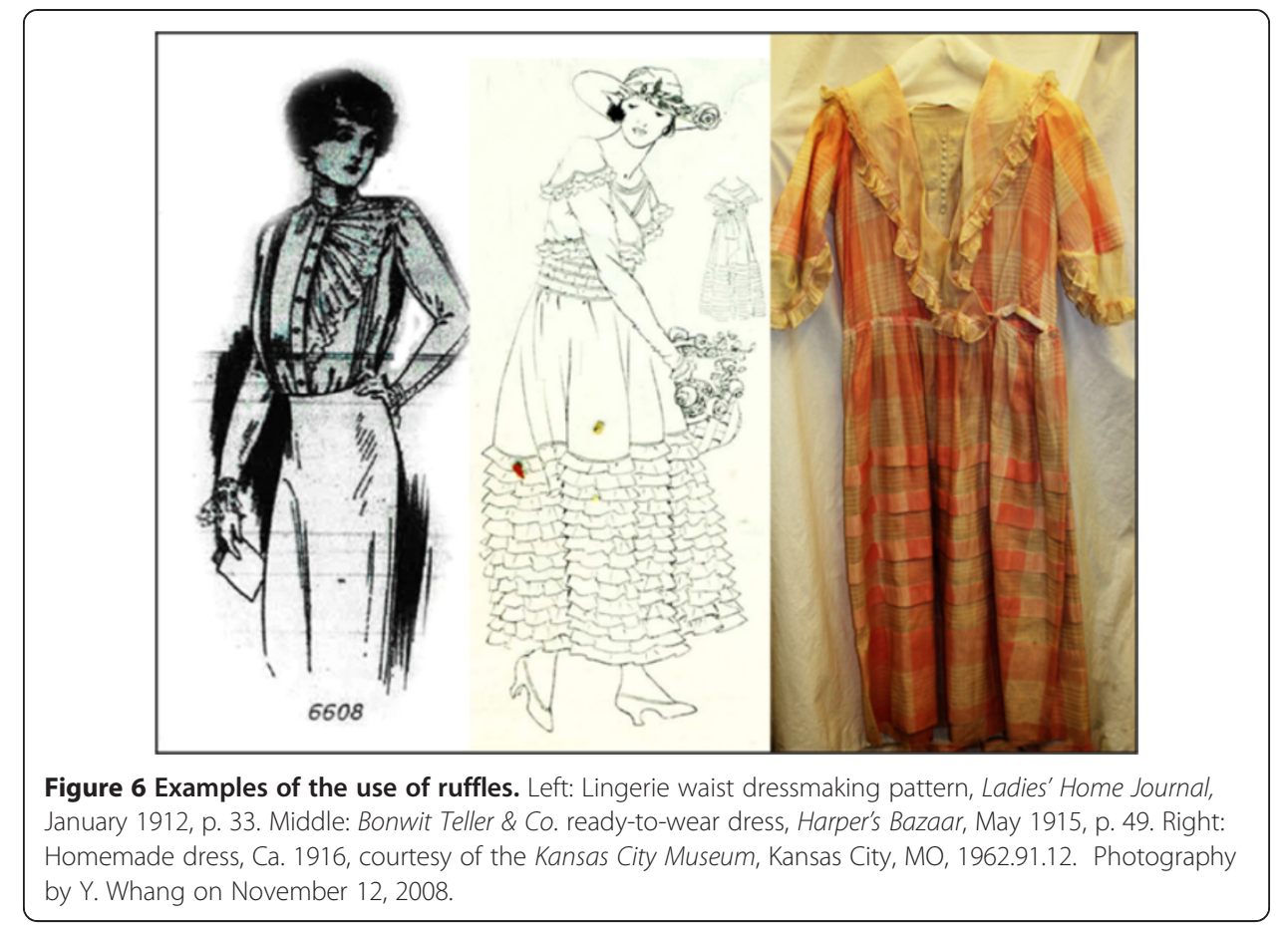

The asymmetrical front closure trend appeared in women's garments that required easy dressing (i.e., daytime clothes, morning wear, business wear, street clothes, and housedresses). The practicality of this design feature was indicated in Ladies' Home Journal as: "a cool, comfortably fitting, easy-to-slip-on dress is an ideal summer possession and something that every woman should have" (Practical summermorning dress 1914, p. 37). Two models on the right in Figure 7 shows dressmaking patterns for business girl's dresses, structured with the asymmetrical front closure and promoted for their ease of wearing in Ladies' Home Journal (Slip-on-easy dress 1911). Dressmaking patterns (three models on the left, Figure 7) for street, afternoon, or house dresses with tunic style cut are further examples designed with an asymmetrical front closure. They were described as being popular for the most updated housedresses if made of gingham or percales, as well as for street and afternoon dresses (Home Pattern Company 1995). The front closure in women's apparel was clearly apparent in the garments that required easy putting on and taking off. A fashionable adaptation of that feature was the asymmetrical placement of the front closure, which Nelly Don incorporated into her pink gingham housedress.

The skirt length became shorter and the width wider around 1916 and Nelly Don's 1916 housedress reflected this trend. Although skirt width and skirt length fluctuated, elements of the kimono sleeves, empire waistline, waist yoke, ruffle trimmings, and asymmetrical front closure consistently appeared in a wide range of designs from 1911 to 1916 (Whang 2011). Thus, the design attributes in Nelly Don's 1916 pink gingham housedress were certainly prevalent in a wide range of garment designs from 1911 to 1916. Additionally, Nelly Don assumingly kept up with fashion trends, and that when she designed her housedress, she incorporated them deliberately, ensuring great success in 1916. Her ability to combine fashion with function provided the foundation upon which was built one of the largest ready-to-wear apparel manufacturing companies in the U.S. by 1947. 


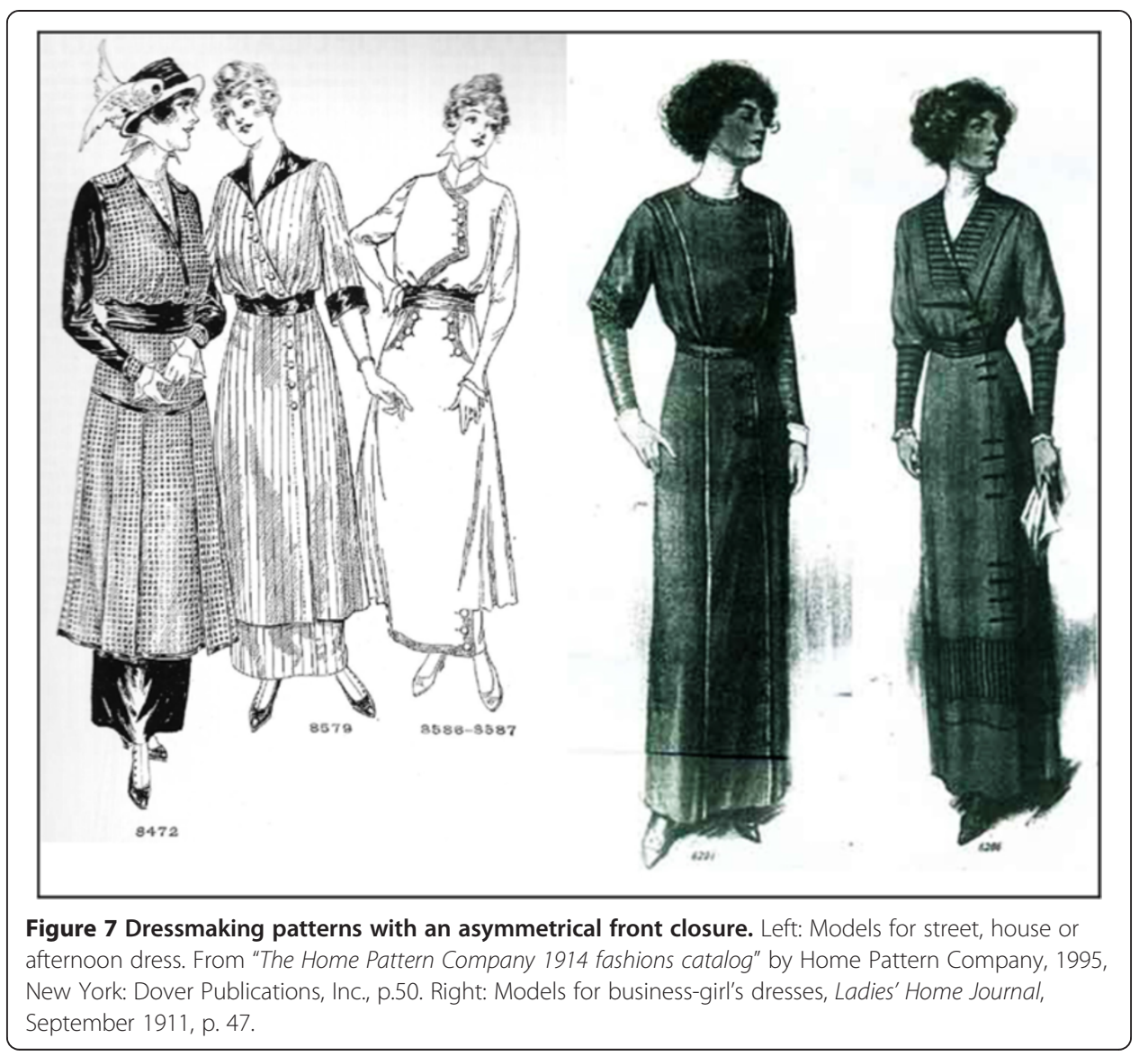

\section{Social appeal: influence of consumption culture}

With the expanded work force and market for mass-produced goods and scientific management instigated by technology-driven industrialization, the U.S. was becoming an industrial society in the early 20th century (Callan 2006). Industrialization also impacted women's work at home before which the family was the core social unit, mostly agrarian, rural, large, and self-sustaining. In pre-industrial households, women spent a great deal of time spinning and weaving cloth, tending garden and poultry, and making clothes, whereas industrial housewives purchased these items mass-produced (Cowan 1976; Connolly 1994; Cross \& Szostak 1995). Households became centers of consumption as the housewife's role transformed from producer to consumer in the early 20th century. However, sewing continued to resonate with feminine work, economic need, women's roles, cultural traditions, and artistic enjoyment and satisfaction (Helvenston \& Bubolz 1999). At this time, most women likely had both home-made and ready-made clothing. However, by 1920 , women bought $80 \%$ of goods for their families (Scanlon 1995), becoming a consumer rather than a producer. Nelly Don's 1916 pink gingham housedress provides an example of this shift.

Cross (2002) wrote that "Consumerism, the belief that goods give meaning to individuals and their roles in society, was victorious even though it had no formal philosophy, no parties, and no obvious leaders" (p. 1), and it was realized "in daily experiences, always changing, improving, and being redefined to meet the needs of individual Americans" (p. 3). Correspondingly, the home was conquered by the market with 
mass circulation magazines, mail-order catalogues, newspapers, and other outlets for advertising domestic goods. Some manufacturers established mail-order firms, others founded department stores and they all used mass-media to promote their merchandise, which helped push a consumer-oriented culture. The wide range of clothing options, prices, and the various outlets for disseminating and selling those clothes promoted desire by overwhelming browsers with so much accessibility. Such availability and access led to the desire to purchase, which in turn encouraged consumerism (Lears 1983).

In the 1910s in the Kansas City area, before the full-scale department store was established, only dry goods retailers such as Peck's Dry Goods Company existed where Nelly Don took her housedress. Dry goods stores sold ready-to-wear clothing, hosiery, gloves, underwear (Linhoff Dry Goods Co. 1916), as well as dress goods (e.g., ginghams, calicos, percale, lawns, batiste, sateen, and muslin), ribbons, buttons, handkerchiefs, "fancy work" supplies, yarn and knitting needles, tea towels, and so forth (Landis 1986). Women in the Kansas City area had the options of purchasing housedresses either through mail-order catalogs or at local dry goods stores unless they hired professional dressmakers or sewed themselves.

Meanwhile, general mail-order catalogs such as Montgomery Ward and Sears provided rural dwellers with fashion news and trends as well as a variety of yard goods and ready-made clothes with value, style, and a reasonable price. Specialty clothing mail-order firms such as Bellas Hess E Co., The Bedell Company, Perry, Dame E Co., Philipsborn, National Cloak \& Suit Co., Allen, Brockman E Smith, and Simpson Crawford Co. often provided the latest "New York style" or "Paris fashion" at affordable prices. The department stores such as Gimbel and Altman also flourished and published a mailorder catalog to reach consumers; stressing their ready-made garments had value, quality, and style. For instance, a caption in Gimbel's catalog clearly emphasized its marketing strategy focusing on value, "this charming morning frock is a splendid example of Gimbel style in the famous Gimbel quality and at a money-saving price that is characteristic of Gimbels" (Gimbel Brothers 1994 p. 8). In addition, influences of high fashion from abroad were promoted, "The newest of modes of Paris reproduced by Gimbel” represented "The Paris of America” (Gimbel Brothers 1915, p.7). Even those who could not afford a stylish, high-end garment were made aware of current modes of fashion from such appealing presentations.

Waller-Zuckerman (1989) stated that ladies' magazines and advertising played a role in promoting mass-produced ready-to-wear. She noted this feasibility since, in the early 20th century, circulation soared showing consumers could be reached this way. As such, ladies' magazine's pages were sought by advertisers. Thanks to expanding readership and growing advertising revenues, Benson (1986) noted, ladies' magazines could influence and entice women to look, dream, and purchase as department stores did. The advertisements portrayed in Figure 8 promoted the housedress by appealing to the housewives' desire for fashion, practicality, and comfort, and at the same time offering value with good quality and reasonable price. Bellas, Hess \& Co (1913), a fashion mail-order firm, urged consumers to purchase their "neat, serviceable, well-made house dress" at $\$ 1$ by stating that "If you do [keep your house], you will be charmed with this practical, comfortable and becoming house dress and sweeping cap" in Ladies' Home Journal (p. 32) (Figure 8). The ad also portrayed its fashionable design features including pretty cuffs, contrasting color piping, and fine pearl buttons. An ad for Allen et al. (1914) 


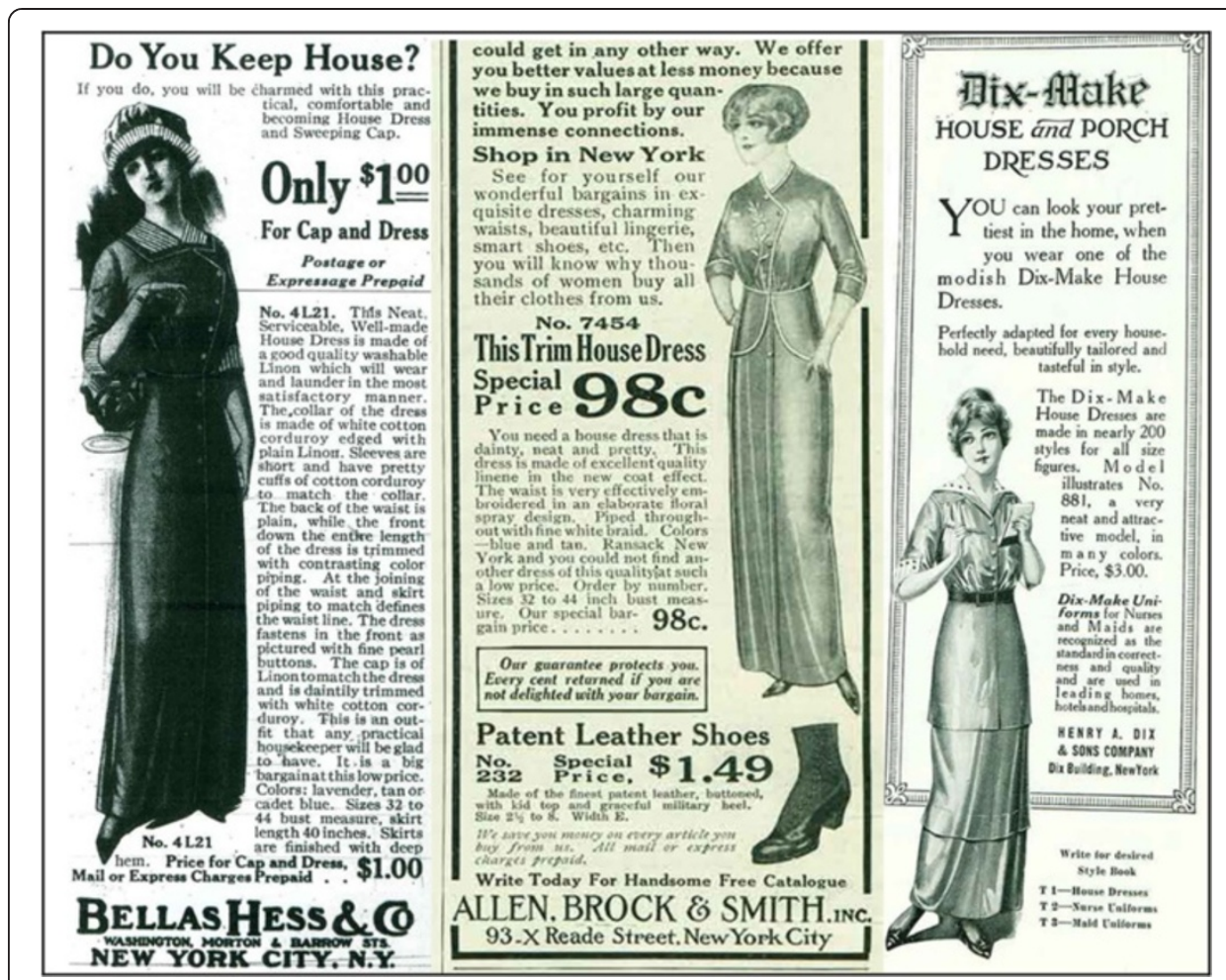

Figure 8 Advertisements promoting attractive and practical housedresses. Left: Bellas Hess \& Co. ad in Ladies' Home Journal, January 1913, p. 32. Middle: Allen, Brockman \& Smith ad in The Delineator, March 1914, p. 75. Right: Ad for Dix-Make housedress in Harper's Bazaar, March, 1915, p. 107.

"trim house dress" from The Delineator, offered consumers better values at less cost as they buy in large quantities, urging that "you need a housedress that is dainty, neat and pretty" (p. 75) (Figure 8). Dix-Make (1915), a uniform manufacturing company, claimed in an ad from Harper's Bazaar (Figure 8) that "you can look your prettiest in the home, when you wear one of the modish Dix-Make house dresses" (p. 107). Another Bellas, Hess \& Co (1914) housedress was advertised as a "neat, well-made house or porch dress of pretty style, made of high-grade washable striped gingham," priced also at only $\$ 1$ in The Delineator (p. 43). This page also described the fine and practical quality of the fabric's fast colors along with detailed design features such as "becoming vest effect of plain gingham to match color of stripe in material," "little striped revers at neck," and "contrasting gingham-covered buttons".

The middle-class housewife who previously had to sew at home now had affordable, tasteful ready-made clothes options, which perhaps hastened her transformation into consumer. Considering the forces behind consumption of goods in the 1910s, middle-class white American women (the target consumer groups of ladies' magazines) (Waller-Zuckerman 1989), would be exposed to and desire the pretty housedresses advertised in magazines and catalogs. Furthermore, this same consumer group could be predisposed to recognize and purchase the modern, pretty, and reasonably priced Nelly Don housedress, and so her success in 1916 likely fits within the framework of emergent cultural and social trends.

In brief, although mail-order companies produced dresses for other occasions, they used housedresses as their main illustrated item in their ads. It probably indicates not 
only the company's intention to sustain a woman's attention with the value of their product, but also that they understood a woman no longer wanted to wear drab looking, self-made housedresses, even at home. Consequently, ads catering to the middle-class housewives predictably encouraged a desire to look pretty even at home. A housewife who did not have enough time or skill in the art of dressmaking might have purchased one of those housedresses in the ads, or if she was skilled at sewing, she might have purchased a housedress pattern or tried to copy one from an ad. Thus, the advertisements in ladies' magazines surely could have influenced a housewife to want to appear as the women in the ads were portrayed. The advertisers of the time employed strategies promoting a desire to look fashionable and at the same time promoting housedresses with value (i.e., quality, practicality, low price, a variety of styles with attractive design features) within the reach of the middle-class income (Whang 2011). Thus, considering the factors of consumption culture in the 1910s, it is reasonable to assume that middle-class white American women would be exposed to and desire the pretty housedresses advertised in magazines and catalogs and seen in major department stores. The same consumer segment in the Kansas City area could be predisposed to recognize and purchase the modern, pretty, and competitively priced Nelly Don housedress. This social aspect along with the design appeal of Nelly Don's 1916 pink gingham housedress brought her success. In this way, her housedress reflected social and cultural change in this transitional period, and exemplified the shifting role of the middle-class American housewife by offering an alternative to the Mother Hubbard as well as a lifestyle free of long hours spent sewing.

\section{Conclusion}

Our thesis is that Nelly Don's 1916 housedress was well-accepted due to its design and social appeal. Mass advertising and articles in mass media promoted fashion sensibility and instilled in consumers a desire to look as pretty as the women portrayed in the ad or article. In contrast, the women who wore the Mother Hubbard at home in the 19th century may not have been as conscious of their images as perhaps the early 20th century women who were inundated with advertising images and fashion articles. Consumerism influenced women's perceptions and preferences for dress, enticing them to emulate the advertised persona and images. We believe that the popularity of Nelly Don's pink gingham housedress fits here. The women who purchased Nelly Don's stylish, yet practical housedress had been predisposed through mass media to desire a fashionable housedress. The principle of consumption reached its peak in the 1920s (Cross 2002) paralleling the burgeoning success of Nelly Don's Donnelly Garment Company.

However, if Nelly Don's pink gingham housedress had not been well designed, those women eager to emulate the images displayed in the ads and fashion articles in the magazines would not have purchased the housedress. Nelly Don successfully integrated elements desired by the middle-class white American housewife in the early 20th century into a housedress: stylish fashion, feminine charm, and practicality. The frock's stylish fashion was exemplified in the empire cut, kimono sleeves, yoke design, and asymmetrical front closure; ruffle trimmings demonstrated feminine charm; and the front closure achieved practicality, which was reinforced by the shorter skirt length, wider skirt width, and the durable, washable gingham fabric. In other words, the pink 
gingham housedress exemplified where high fashion elements met practicality while preserving the feminine charm in a dress for everyday wear. It blurred the distinction between public and private fashion by integrating both elements. In addition to her design elements, Nelly Don offered the average housewife a purchasing alternative and simultaneously a modern lifestyle free of long hours spent sewing. Furthermore, the pink gingham housedress was one of those housedresses that could be worn for housework, out on the street for an errand, or for visiting a friend. Thus, Nelly Don's 1916 pink gingham housedress served as a material culture example illustrating the middle-class white American housewife's shifting role from producer to consumer in the early 20th century.

\section{Consent}

Written informed consent was obtained from the patient for the publication of this report and any accompanying images.

Competing interests

The authors declare that they have no competing interests.

\footnotetext{
Author details

${ }^{1}$ Communication and Fine Arts, Centenary College, 400 Jefferson St., Hackettstown, NJ 07840, USA. ${ }^{2}$ Apparel, Textiles, and Interior Design, Kansas State University, 339 Justin Hall, Manhattan, KS 66506, USA.
}

Received: 29 July 2014 Accepted: 9 October 2014

Published online: 18 November 2014

\section{References}

Allen, Brockman, \& Smith. (1914). The Delineator (p. 75).

Austin, A. (1906). Good Housekeeping, 43(2), P.186 (Retrieved from Home Economics Archive: Research, Tradition and History, Cornell University (HEARTH)).

Bellas, Hess \& Co. (1913). Ladies' Home Journal (p. 32).

Bellas, Hess \& Co. (1914). The Delineator (p. 43).

Benson, SP. (1986). Counter culture: Saleswoman, managers, and customers in American department stores, 1890-1940. Urbana, IL: University of Illinois Press.

Bonwit Teller \& Co. (1915). Harper's Bazaar (p. 49).

Calasibetta, CM, \& Tortora, P. (2003). The dictionary of fashion (3rd ed.). New York: Fairchild Publications, Inc

Callan, J. (2006). Decades of American history: America in the 1900's and 1910's. New York: Facts on File, Inc.

Coats and coat suits for spring. (1914). Ladies' Home Journal (p. 95).

Connolly, MA. (1994). The transformation of home swing and the sewing machine in America, 1850-1929. Retrieved from ProQuest Digital Dissertations \& Theses. (AAT9315947).

Cowan, RS. (1976). The "Industrial Revolution" in the home: Household technology and social change in the 20th century. Technology and Culture, 17(1), 1-23.

Cross, G, \& Szostak, R. (1995). Technology and American society: A history. Upper Saddle River, New Jersey: Prentice Hall.

Cross, G. (2002). An all-consuming century: Why commercialism won in modern America. New York, West Sussex: Columbia University Press.

Dainty summer gowns. (1898). Harper's Bazaar, 31 (14). P. 295. Retrieved from Home Economics Archive: Research, Tradition and History, Cornell University (HEARTH).

Dix-Make. (1915). Harper's Bazaar (p. 107)

Ewing, E. (2001). History of 20th century fashion (Revth ed.). New York: Costume \& Fashion Press.

Gimbel Brothers. (1915). Harper's Bazaar (p. 7).

Gimbel Brothers. (1994). Gimbel's illustrated 1915 fashion catalog. New York: Dover Publications, Inc. (Republication of the Paris London and American Styles, Spring and Summer 1915 Issue, published by Gimbel Brothers, New York, Philadelphia, 1915.

Helvenston Gray, S. (n.d.). The multi-functional Mother Hubbard. "Manuscript in preparation".

Helvenston, SI, \& Bubolz, MM. (1999). Home economics and home sewing in the United States, 1870-1940. In B Burman (Ed.), The culture of sewing: Gender, consumption and home dressmaking (pp. 303-325). New York: Berg.

Hill, DD. (2004). As seen in vogue: A century of American fashion in advertising. Lubbock, Texas: Texas Tech University Press.

Home Pattern Company. (1995). The Home Pattern Company 1914 fashions catalog (p. 50). New York: Dover Publications, Inc.

Kidwell, CB, \& Christman, MC. (1974). Suiting everyone: The democratization of clothing in America. Washington, D.C.: Smithsonian Institution Press.

Kim, HJ, \& Delong, MR. (1992). Sino-Japanism in Western women's fashionable dress in Harper's Bazar, 1890-1927.

Clothing and Textiles Research Journal., 11(1), 24-30.

Landis, M. (1986). Several names for dry goods store. In The Kansas City Kansan (p. 3B). 
Lears, TJJ. (1983). From salvation to self realization. In RW Fox \& TJJ Lears (Eds.), The culture of consumption: Critical essays in American history, 1880-1930 (pp. 1-38). New York: Pantheon Books.

Linhoff Dry Goods Co. (1916). The Democrat-Tribune, 40 (56), p. 1. Retrieved from NewspaperARCHIVE. http://www.newpaperarchive.com/PdfViewerTags.aspx?img=99377526\&currentResult=1\&src=Search.

Long, A. (1914). What I see on Fifth Avenue. In Ladies' Home Journal (p. 24).

Maternity frocks. (1915). Good Housekeeping, 61(1) (p. 106). Retrieved from Home Economics Archive: Research, Tradition and History, Cornell University HEARTH.

McMillen, MF, \& Roberson, H. (2002). Called to courage: Four women in Missouri history. Columbia, MO: University of Missouri Press.

Mears, P. (2005). Orientalism and opulence. In G Buxbaum (Ed.), Icons of fashion: The 20th century (pp. 18-19). New York: Prestel.

Merritt, BG. (1912). What I see in New York. In Ladies' Home Journal (p. 33).

Ogden, AS. (1986). The great American housewife: From helpmate to wage earners. 1776-1986. Westport, CT: Greenwood Press.

O'Malley, TM. (2006). Nelly Don: A stitch in time. MO: The Covington Group.

One-piece work dress. (1910). Ladies' Home Journal (p. 34).

Practical summer-morning dress. (1914). Ladies' Home Journal (p. 37).

Progressive Era in America (n.d.). Retrieved January 29, 2011 from http://www.questia.com/library/progressive-era.jsp.

Scanlon, J. (1995). Inarticulate longings: The Ladies' Home Journal, gender, and the promises of consumer culture. New York and London: Routledge.

Schneider, D, \& Schneider, C. (1993). American women in the Progressive Era, 1900-1920. New York: Facts On File.

Slip-on-easy dress. (1911). Ladies' Home Journal (p. 47).

Snider, A. (1991). Nell Donnelly reed is dead at age 102. In The Kansas City Star (pp. A-1-A-9).

Spilsbury, B. (1952). [Letter to the editor]. The Kansas City Star from Kansas City. Missouri.

Stan, E. (1908). Our special patterns: Designed for Good Housekeeping. In Good Housekeeping, 45(1) (pp. 64-72). Retrieved from HEARTH.

Tortora, P, \& Eubank, K. (2010). Survey of historical costume (5th ed.). New York: Fairchild Publications.

Waller-Zuckerman, ME. (1989). winter). Old home in a city of perpetual change: Women's magazines, 1890-1916. Business History Review, 63(4), 715-756.

Wash dresses that are neat and feel comfortable. (1916). Montgomery Ward Co (p. 110). 1916 Spring/Summer Catalog. Watson, KH. (1907). Textiles and Clothing. Chicago: American School of Home Economics. Retrieved form HEARTH.

Wilding, J. (1987). First a lady: The unlikely story of gentlewoman Nell Donnelly, tycoon. In Star Magazine (pp. 8-11).

Wilson, L, \& Newby, R. (2004). Fashion. In R Newby (Ed.), The Rocky mountain region: The Greenwood Encyclopedia of American regional culture (pp. 129-159). Westport, CT: Greenwood Press.

Whang, M. (2011). Nelly Don's 1916 Pink gingham apron frock: An illustration of the middle-class American housewife's shifting role from producer to consumer (Doctoral dissertation).

doi:10.1186/s40691-014-0018-1

Cite this article as: Whang and Haar: Nelly Don's 1916 pink gingham apron frock: an illustration of the middle-class American housewife's shifting role from producer to consumer. Fashion and Textiles 2014 1:18.

\section{Submit your manuscript to a SpringerOpen ${ }^{\circ}$} journal and benefit from:

- Convenient online submission

- Rigorous peer review

- Immediate publication on acceptance

- Open access: articles freely available online

- High visibility within the field

- Retaining the copyright to your article

Submit your next manuscript at $\gg$ springeropen.com 